\title{
The Taonga of the New Zealand Association of Psychotherapists
}

\author{
Burke Hunter \\ Psychotherapist, Nelson/Te Tau Ihu O Te Waka-A-Māui
}

\begin{abstract}
In this paper the importance of the taonga, treasures, of the New Zealand Association of Psychotherapists, representing the four directions and balance, is explained. Included is how they were used in the opening and closing ceremonies at the Conference in Nelson, 2017. The purpose of this paper is to keep their awareness alive in our Association.
\end{abstract}

\section{Whakarāpopotonga}

Ko tā tēnei tuhinga, he whakatairanga i ngā taonga ā Te Roopū Whakaora Hinengaro o Aotearoa, te whakamārama hoki i ngā ahunga me te whakatairitenga mai i ngā hua e whā. Ka tāpirihia te whakatinanatanga o ènei i te whakatuwheratanga me nga katinga o te Hui Wānanga i Whakatū i te tau 2017. Ko te kaupapa o tā tēnei pepa he whakamau ake i tō rātau aroā i roto i tō tātau Roopū.

Keywords: ritual; taonga; pōwhiri; poroporoaki

Donna Henes (2013) wrote in an article, "Why We Need Ritual in Our Lives”,

The need for ritual is a basic human instinct, as real, as urgent and as raw as our need for food, shelter and love. And it is every bit as crucial to our survival. A compelling urge to merge with the infinite, ritual reminds us of a larger, archetypal reality and invokes in us a visceral understanding of such universal paradigms as unity, continuity, connectivity, reverence and awe. (para.1)

As there are many forms of Māori ritual, depending on the kawa/protocols of each iwi, so too there are many forms of Pākehā/Tauiwi ceremony and ritual. We are presenting here

Hunter, B. (2017). The taonga of the New Zealand Association of Psychotherapists. Ata: Journal of Psychotherapy Aotearoa New Zealand, 21(1), 13-16. https://doi.org/10.9791/ajpanz.2017.02 @ New Zealand Association of Psychotherapists Inc. 
one ritual offered to our Association at the Nelson Conference to bring our taonga alive.

In March 2017, the New Zealand Association of Psychotherapists (NZAP) held our conference in Nelson. In our conference booklet we wrote of the history of these taonga. "As we give energy to these symbols we grow in consciousness" (NZAP, 2017, p. 5).

The Harakeke Plait (Earth) 2001: In 2001 at the Wellington Conference a harakeke plait was woven by Mihiteria King and indicates the ways we are intertwined together in our association, Māori and Pākehā/ Tauiwi.

The Conference Candle (Fire) 2002: The candle represents the light that we all bring to our Association. In 2002 at the Nelson Conference the late Trudy McKay suggested that we have a candle to light throughout the conference. It was lit each morning with a karakia/prayer/reflection. It was put out at the end of each day. This candle was then passed onto [sic] the next conference committee at the handover at the end of the conference. (NZAP, 2017, p. 5)

(The candle was replaced in Nelson in 2010 and again in 2017 with the current candle).

The Singing Bowl (Air) 2015: This was presented at the Christchurch 2015 Conference to go as their gift to each future Conference. It calls us together through the gift of sound. (NZAP, 2017, p. 5)

Added to these three taonga was the Paua Water Container (Water) 2017: at the recent Nelson Conference this gift was presented. It holds water and is the container of emotions.

The Four Symbols/Taonga, each year, will move from conference to conference. They help us to focus together at each conference, starting and ending each day with consciousness in our gathering together. (NZAP, 2017, p. 5)

Recently in NZAP there has been discussion in terms of celebration, that Mãori ritual is evident but that Pākehā/Tauiwi ritual seems to be missing. This year we took on the task of seeing that the ritual taonga of our Association were brought fully alive and into our consciousness at this conference, particularly since we added the fourth taonga, the Paua Water Container, so that all four elements were present. We wanted to introduce each of these and speak of their significance to our Association.

We spoke to each of the four directions and then asked a question in relation to that energy for each of us in our Association.

The East: sounding the Singing Bowl we honoured the East, direction of dawn, Spring and new birth calling us together with the gift of sound. The element is air, breath of life, gently breezed and also the hurricane and tornado. We honoured our taonga, the symbol for the East, this singing bowl given to us in Christchurch in 2015.

Question: How do we bring new life into the association? How do we acknowledge and express our thoughts within NZAP?

The North: the Candle presented in 2002, the gift of fire. The candle was lit. We honoured 
the North, direction of the noonday sun, the Summer. Fire, the giver of warmth that warms us and yet can also burn. We honoured our taonga, the symbol of the North.

Question: How do you kindle the fire within NZAP? How do you share your passion within our Association?

The West: the Paua Water Container presented at this Conference. It was filled with the water from the local awa, the Maitahi River, that runs through the centre of Nelson. It gives us the water to sustain all life. It quenches our thirst, it is the flow of our tears, and also it floods. We honoured the West, direction of dusk, Autumn and our tūpuna/ancestors.

Question: How do we experience, express and share our emotions as part of NZAP?

The South: the Harekeke Plait, our first taonga from 2001, that represents the intertwining relationship in NZAP between Māori and Pākehā/Tauiwi. We honour the South, direction of midnight and Winter, the going within, reflecting place. The earth which holds and nurtures us, but that also can cause earthquakes, shake us up and take life.

Question: How do you let go of what is no longer needed? How do you look after yourself? What needs to end so that something new can begin?

The conference was opened at the Whakatu Marae with a pōwhiri, a Māori ritual of welcome and joining together as one. This ritual occurred on the next morning and also at the close of the Conference before the poroporoaki/farewell when the candle was extinguished and the water was returned to the river. We acknowledged that these taonga are precious and that they are alive to us. They will help us to grow in consciousness. They are now part of our heritage. They have a history and lineage/whakapapa.

We are very fortunate in Aotearoa to have a connection with tangata whenua, the Mãori people of the land. They remind us of the richness and ritual of their culture that can enliven us. With the ritual of our cultures being shared together we can also enliven them.

In closing I quote Donna Henes' article on ceremony.

Ceremonial observance adds lucid layers - depth, dimension, drama and distinction - to our lives, making the ordinary seem special, and the special, extraordinary. Through the practice of ritual we are privileged to experience ourselves as prepared, present, passionate, principled and potent. When we set aside the quality time and claim the psychic space for ceremony, when we assume the authority to do so, we are able to transform our perceptions, our perspectives, our experiences, and in the process, our reality. (2013, para. 7)

\section{References}

Henes, D. (2013, May 17). Why we need rituals in our lives. Huffington Post. Retrieved from http:// www.huffingtonpost.com/donna-henes/rituals_b_3294412.html

New Zealand Association of Psychotherapists. (2017, March 9). NZAP conference booklet.Nelson, Aotearoa New Zealand: NZAP. 


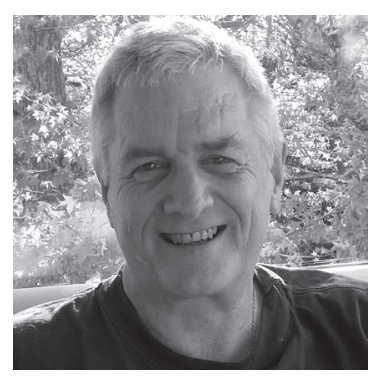

Burke Hunter is a psychotherapist living in Nelson and a member of the Te Tau Ihu Branch of NZAP. He has been a psychotherapist for 25 years. He is a member of the Te Tirtiti Bicultural Advisory Committee. Contact details: burkewhunter@gmail.com . 